виконання начерків та зарисовок різноманітних об'єктів, предметів; створення сюжетних композицій на основі спостережень, творчої інтерпретації. Варто зазначити, що важливим чинником професіоналізму вчителя образотворчого мистецтва є здатність педагога до творчої уяви та фантазії, креативно мислити, вміння імпровізувати [5, с. 211].

Отже, професійна майстерність студентів художньо-графічних факультетів полягає в оволодінні ними не лише дисциплінами психолого-педагогічного циклу, але й знаннями, уміннями та навичками художньо-графічного та декоративноприкладного характеру. У педагогічній роботі студенти синтезують художньопрактичні та психолого-педагогічні знання та навички, що $є$ запорукою успішного здійснення їх професійної діяльності. Важливим специфічним складником професійної майстерності студентів художньо-графічних факультетів $є$ практичні уміння та навички. Джерелом їх формування $є$ самостійна практична діяльність студентів, яка виявляється у формі зарисовок, начерків, ескізування тощо. Систематизоване їх виконання сприяє розвитку творчих здібностей майбутнього вчителя образотворчого мистецтва, формуванню його особистості та зростанню професійної майстерності. Постійний самоконтроль, здійснюваний студентами, постановка відповідних завдань, послідовне оволодіння методами виконання практичних рисунків, допомагає оволодіти цим видом образотворчої діяльності.

\title{
Література
}

1. Бабанский Ю. К. Оптимизация процесса обучения / Ю. К. Бабанский. - М. : Педагогика, 1977. - 256 с. 2. Багаева И. Д. Профессионализм педагогической деятельности и основы его формирования у будущего учителя: автореф. дис. на соискание ученой степени д-ра. пед. наук: 14.00.14 / Багаева И. Д. - Л., 1991. - 36 с. 3. Гончаренко С. У. Професійна освіта: [навч. посіб.] / С. Гончаренко. - К. : Вища шк., 2000. - 380 с. 4. Зязюн І. А. Педагогічна майстерність / І. А. Зязюн. - К. : Вища шк., 1997. - 349 с. 5. Кардовский Д. Н. Об искусстве / Д. Н. Кардовский. - М. : Искусство, 1960. - 281 с. 6. Ростовцев Н. Н. Учебный рисунок: [учеб. пособ.] / Н. Н. Ростовцева. - М. : Просвещение, 1976. - 288 с.

УДК 378.147:[37.011. - 051]:62/64

Зоя Кучер

\section{ФОРМУВАННЯ ПРОФЕСІЙНО-ПЕДАГОГІЧНОЇ КОМПЕТЕНТНОСТІ МАЙБУТНЬОГО ВЧИТЕЛЯ ТЕХНОЛОГІЙ У МОДУЛЬНІЙ СИСТЕМІ НАВЧАННЯ}

Кучер 3. С. Формування професійно-педагогічної компетентності майбутнього вчителя технологій у модульній системі навчання.

У статті розкрито сутність поняття «професійно-педагогічна компетентність». Визначено принципи побудови професійно-орієнтованих модульних програм та умови їх реалізації в технологічній освіті. Особливу увагу звернено на процес неперервності вивчення спеціальних дисциплін швейного напрямку та використання проектних технологій.

Ключові слова: професійно-педагогічна компетентність, модульна програма, проектні технології, технологічна освіта.

Кучер 3. С. Формирование профессионально-педагогической компетентности будущего учителя технологий в модульной системе обучения.

В статье раскрыто сущность понятия «профессионально-педагогическая 
компетентность». Определено принципы построения профессиональноориентированных модульных программ и условия их реализации в технологическом образовании. Особое внимание обращено к непрерывности изучения специальных дисциплин швейного направления и использования проектных технологий.

Ключевые слова: профессионально-педагогическая компетентность, модульная программа, проектные технологии, технологическое образование.

Kucher Z. S. Forming of professional and pedagogical competence of a future teacher of technologies in the modular training system.

The article deals with the concept "professional and pedagogical competence". Principles of making professionally oriented modular programs and conditions of their implementing in technological education are defined. The special attention is given to continuity of studying the special disciplines like sewing and using project technologies.

Key words: professionally pedagogical competence, modular program, project technologies, technological education.

Підготовка педагогів з високим рівнем технологічної освіти, які в подальшому будуть спроможні здійснювати допрофесійну та професійну орієнтацію школярів на різнопланові професії, що необхідні в певний період та у визначеному регіоні, $\epsilon$ основним запитом сучасного суспільства.

Особливість підготовки вчителя технологій полягає в тому, що 3 психологопедагогічною та методичною підготовкою необхідно поєднувати різнопланову спеціальну підготовку, а саме: декоративно-прикладну, художню, конструкторську, проектну, технічну, технологічну. Нинг має місце об'єктивна необхідність дослідження проблеми вдосконалення підготовки вчителів технологій у двох напрямках - педагогічному та технологічному, що спрямовує науковців на пошук інноваційних педагогічних технологій, додаткових ресурсів, залучення нових інформаційних технологій у навчальний процес.

Світовий досвід навчання у вищій школі показує, що в основу освітнього процесу необхідно покласти не навчання знань і теорій, що підтримується практикою, а засвоєння професії, тобто залучення студента як можна раніше до реальної практичної діяльності (дослідницької, інженерної, проектувальної, управлінської, викладацької й тощо). Необхідно, щоб студенти засвоювали засоби, методи, принципи мислення, основні проблеми в галузі застосування знань та теорій, орієнтувались у різних наукових дисциплінах.

Метою статmі є науково-теоретичне обгрунтування педагогічних умов формування професійно-педагогічної компетентності майбутніх учителів технологій.

Різні аспекти проблеми професійно-педагогічної підготовки вчителів технологій набувають особливої актуальності й розробляються в багатьох напрямах на сучасному етапі. Науковою базою для нас були дослідження С. Батишева, О. Коберника, В. Сидоренка, В. Симоненка, Д. Тхоржевського та ін.

Нас цікавили різні напрямки дослідження означеної проблеми: Л. Волошко формування професійної компетентності майбутніх фахівців 3 фізичної реабілітації у процесі вивчення медико-біологічних дисциплін; Н. Банько - формування професійно-педагогічної компетентності як компонента професійної підготовки менеджера.

3-поміж сучасних публікацій, присвячених зростанню вимог до фахової підготовки саме вчителів технологій, іiі складникам і характеристикам, слід назвати такі: О. Хищенко - професійно-педагогічна підготовка майбутніх учителів 
технологій); О. Чернишова - формування професійної компетентності майбутніх педагогів у розвитку технологічного мислення, О. Гур'янова - зростання вимог до фахової підготовки вчителів технологій та проблема їх забезпечення); Н. Борисенко професійна підготовка майбутніх учителів технологій в умовах сучасного освітнього простору та ін.

Більшість науковців мають спільну думку, що поняття «компетентність» ширше, ніж знання, уміння та навички і не є їх сумою, оскільки передбачає різні сфери діяльності - знаннєву, ціннісно-мотиваційну, операційно-технологічну, художньотворчу. У науковій літературі зазначено, що зміст поняття «компетентність» охоплює, окрім загальної сукупності знань, знання можливих наслідків конкретного способу впливу, рівень умінь та досвід практичного використання знань. Термін «компетентний» означає «відповідний», «здатний». Поняття «компетенція» розглядається як «коло питань», «знання та досвід у тій чи іншій галузі».

Л. Хазова зазначає, що «компетентність не прив'язана жорстко до певних освітніх стандартів, змісту чи інших цінностей. Змінюються ситуації, змінюються культурні зразки, змінюються самі люди, їх запити та можливості- при цьому інваріантним залишаються вимоги компетентності. Сама ця цінність $є$ надзвичайно стійкою, але саме завдяки рухливості наповнення компетентності у змінному часі» $[6$, с. 3$]$.

Освітні компетенції охоплюють основні освітню галузь і навчальні предмети. Такі компетенції відбивають предметно-діяльнісний складник загальної освіти і мають забезпечувати комплексне досягнення поставлених цілей. Недостатньо студентам на високому рівні опанувати необхідні теоретичні знання, необхідно застосовувати ці знання задля розв'язання конкретних завдань чи проблемних ситуацій. Освітня компетенція передбачає засвоєння студентом не окремих фрагментів знань та вмінь, а оволодіння комплексною процедурою, у якій для кожного виокремленого напряму наявна відповідна сукупність освітніх компонентів, що мають особистісно-діяльнісний характер.

Сутність професійно-педагогічної компетентності трактується науковцями порізному. У визначення професійно-педагогічної компетентності майбутнього вчителя технологій вкладається неоднозначний смисл: В. Штейнберг, Е. Нікіфорова розглядають ii як проектно-технологічну компетентність; Ю.Дорохін, A. Вербицький - як предметно-технологічну; компетентність; Д. Санніков - як конструкторсько-технологічну.

Професійно-педагогічну компетентність Н. Банько визначає як інтегративну властивість особистості, що виражається в сукупності компетенцій у психологопедагогічній галузі знань; здібності активно впливати на процес розвитку й саморозвитку соціально-ціннісних характеристик особистості [2].

Професійна компетентність, на думку Г. Балихіна, передбачає гармонійне поєднання праці та творчості людини, які різняться, по-перше, тим, що метою праці $є$ виробництво благ, послуг, а метою творчості - самореалізація особистості творця; подруге, мотив праці - зовнішній, мотив творчості - внутрішній, особистісний; по-третє, продукт праці - відчужуваний, відтворюваний, матеріальний, а продукт творчості, як правило, невідчужуваний, проте може існувати як у відчужуваній (витвір мистецтва, література тощо), так i в невідчужуваній нематеріальній формі (почуття самореалізації, задоволення результатами діяльності, розвиток особистісних якостей) [1, с. 123].

О. Чернишова вважає, що професійна компетентність - це інтегроване, багатоаспектне поняття, показник особистісного зростання та професійної 
майстерності. Під професійною компетентністю педагога О. Чернишова розуміє рівень його знань і професіоналізму, що дозволяє приймати правильні рішення в кожній конкретній педагогічній ситуації. «Компетентність»- це ситуативна категорія [6].

Психологи наголошують, що професіоналізація майбутнього фахівця визначається здатністю застосовувати здібності та набуті знання, вміння та досвід у галузі обраної професії, набуття його здійснюється у процесі суб'єктної, тобто предметної, реальної, змістової, творчої навчальної діяльності, яка має самостійний характер, свідомо й цілеспрямовано виконується людиною в умовах спільної діяльності та взаємодії суб'єктів.

Професійно компетентний спеціаліст сам ставить цілі своєї діяльності, визначає шляхи та засоби їх досягнення, несе відповідальність за наслідки іiі реалізації. Кваліфіковані спеціалісти можуть на високому рівні виконувати свої професійні обов'язки, дотримуватися правил, але їх компетентність залишається невиявленою під час виконання нестандартних ситуацій. Компетентність, критична оцінка, експертність, а не знання, вміння і навички цінуються в сучасних життєвих ситуаціях.

Однак наявність відповідної освітньої кваліфікації випускника вищого навчального закладу як претендента на зайнятість ще не гарантує успішного виконання ним професійних функцій і потребує періоду довготривалої адаптації, набуття досвіду.

Професійна підготовка майбутніх учителів технологій, на думку Н. Борисенко, є необхідною передумовою їх становлення як професіоналів - соціально компетентних, психологічно зрілих особистостей, що володіють високою фаховою майстерністю, сучасним світоглядом, потребою розширювати й поглиблювати власну компетентність 3 освітньої галузі «Технологія» [3, с. 296]. Автор виокремлює три основні структурні елементи змісту освіти, що має бути системним і охоплювати: досвід пізнавальної діяльності, зафіксований у формі вмінь діяти за зразком; досвід творчої діяльності - у формі вмінь приймати нестандартні рішення у проблемних ситуаціях; досвід здійснення емоційних відношень- у формі особистісних орієнтацій [3, с. 298].

М. Іголкіна забезпечення компетентнісного підходу в підготовці вчителя вбачає у трьох аспектах:

- Компетентнісний підхід у професійній підготовці інженера $є$ цілісною освітньою стратегією і практикою, спрямованою на персоніфікацію підготовки майбутнього спеціаліста та його становлення як суб'єкта інноваційно-образотворчої діяльності. Для повноцінного забезпечення цього підходу в інженерній освіті необхідний новий соціокультурний формат розуміння інженерної діяльності, який означає, що професіоналізм і компетентність інженера визначаються його знаннями та вміннями створювати та застосовувати технології, наукові досягнення задля забезпечення стійкого розвитку суспільства.

- Професійна компетентність інженера є якісним особистісним утворенням, що полягає у нерозривній єдності техніко-образотворчої спрямованості особистості та досвіду виробничо-технічної діяльності як суб'єкта. Компетентнісний підхід передбачає побудову такої професійної підготовки, яка, по-перше: постає провідником інженерної культури у змісті навчання; по-друге, здійснює особистіснорозвивальну функцію в методиці й технології навчання; по-третє, реалізує функцію занурення у сферу виробничої та науково-дослідної діяльності в організаційному плані.

- Особистісний план професійної компетентності інженера становить складну 
структуру у вигляді чотирьох взаємопов'язаних компонентів: когнітивного (володіння фундаментальними та прикладними технічними знаннями, інженерним мисленням); операційного (уміння здійснювати проектно-конструкторську, виробничу, науководослідну роботу); споживацько-мотиваційного (прагнення до образотворчоінноваційної діяльності), ціннісно-смислового (цінність інженерної праці та самовираження в ній) [4].

На нашу думку, досягти високого рівня професійної компетентності можна, якщо дотримуватись певних умов формування професійно-педагогічної компетентності:

- неперервність у вивченні спеціальних дисциплін;

- упровадження модульної системи навчання 3 iї повним методичним забезпеченням (що передбачає: інформаційні матеріали, завдання для самостійної роботи практичної спрямованості, тести контролю);

- використання в навчальному процесі комп'ютерних графічних та навчальноконтролюючих програм;

- підготовка студентів до впровадження інноваційних проектних технологій. Зупинимось на деяких із них.

Однією із гострих проблем неперервної професійної освіти $\epsilon$ проблема наступності етапів у системі неперервної підготовки майбутніх учителів технологій.

Низка дисциплін швейного спрямування, що забезпечують оволодіння технологічною освітою за напрямком «Конструювання та моделювання одягу», вивчаються відповідно до такого порядку: 1 семестр- «Обладнання швейного виробництва»; 1-2 - «Матеріалознавство», «Технологія швейного виробництва», 3-4 «Конструювання швейних виробів», «Спеціальний малюнок»; 5 - «Технічне моделювання та художнє оформлення одягу»; 6- «Конструювання засобами комп’ютерної графіки», «Основи композиції»; 4-8 - «Практикум 3 конструювання та технології пошиття швейних виробів»; 7 - курсова робота 3 конструювання та моделювання одягу; 9-10 - «Комп'ютерне моделювання та проектування об'єктів», «Дизайн одягу». Під час складання навчального плану ми обрали доцільну послідовність вивчення дисциплін, що, з нашої позиції, забезпечує наступність їх вивчення та сприяє формуванню професійної компетентності майбутнього вчителя технологій. Кожна дисципліна формує певну частку професійної компетентності.

М. Іголкіна основним методом вважає виконання студентами інноваційнотехнічних проектів. Моделювання та побудова такого середовища здійснювалась засобом розгортання трьох напрямків діяльності:

1) фундаментально-теоретична підготовка, спрямована на залучення до культури інженерного мислення та формування техніко-образотворчої спрямованості особистості;

2) безпосередня практична робота на виробництві, спрямована на формування досвіду інженерної діяльності;

3) науково-дослідна робота, спрямована на залучення до культури інноваційнообразотворчої діяльності [4].

Державний стандарт базової і повної середньої освіти підтверджує, що у процесі вивчення змісту освітньої галузі «Технологія» в основній школі передбачається залучення учнів до проектно-технологічної, інформаційної, художньо-трудової та дослідницької діяльності; розвиток в учнів здатності реально оцінювати свої можливості для вибору посильних творчих завдань. Основою реалізації змістових ліній галузі є проектно-технологічна та інформаційна діяльність, яка інтегрує всі види сучасної діяльності людини: від появи творчого задуму до реалізації готового 
продукту. Проектно-технологічний підхід надасть змогу реалізувати варіативність у змісті трудової підготовки учнів.

Н. Борисенко вважає, що проектно-технологічна діяльність нині активно застосовується на уроках трудового навчання в основній школі, вона покладена в основу сучасних програм трудового навчання для школи. Автор зауважує, що термін «дизайн» у перекладі 3 англійської означає креслення, проект, проектування. Тому необхідно говорити про проектувальну діяльність учнів на уроках трудового навчання як про дизайнерську діяльність. Відповідно необхідно визначити сутність дизайну в ракурсі такого підходу [3 с. 297-298].

В. Тименко вважає, що дизайн-освіта означає «не освітній процес 3 окремого навчального предмета, а міждисциплінарну навчальну діяльність». Дизайн вимагає синтезу навчальної інформації і конструктивного іiі поєднання у творчому процесі. «Дизайн - це комплексна міждисциплінарна проектно-художня діяльність, яка синтезує в собі елементи наукових, технічних і гуманітарних знань. Центральною проблемою дизайну $є$ створення предметного світу, естетично оцінюваного як співмірного, гармонійного, цілісного» [5, с. 7].

Н. Борисенко під «професійною підготовкою вчителів технологій» розуміє деякий спеціально організований процес професійного розвитку фахівця, що забезпечує набуття базових знань, умінь, навичок, практичного досвіду, норм поведінки, які забезпечують можливість успішної роботи з певної професії, і його результат - сформовану готовність до виконання майбутніх професійних завдань [3, с. 298].

О. Чернишова обрала критеріями професійної компетентності майбутнього фахівця: сформованість професійних знань, умінь, навичок, особистісних якостей, які необхідні для його професійної діяльності. Їх набуття здійснюється поступово, виходячи 3 компоненти успішної професійної діяльності майбутнього фахівця професійного відбору, рівня підготовки, особистісних якостей молодої людини, іiі мотивів, прагнень, рівня домагань, первинної професіоналізації у процесі професійної підготовки фахівця відповідно до вимог суспільства (галузевих стандартів вищої технічної освіти), досвіду, кваліфікації, умов праці [6].

Задля виявлення рівня сформованості професійно-педагогічної компетентності нами виокремлено два напрямки: перший спрямований на педагогічний, другий - на технологічний складник професійної компетентності майбутнього вчителя. Специфіка підготовки вчителя технологій вимагає більш глибокого дослідження саме другого етапу.

Науково-дослідна робота здійснювалась у форматі педагогічного супроводу наукової та самостійної роботи студентів, що є результатом у виконанні самостійних інноваційних проектів.

Модульна система навчання передбачає розгорнуте використання завдань самостійної роботи, спрямованих на результат виконання інноваційних проектів. У процесі дослідження відслідковувались такі показники: здатність студентів до організації самостійної проектної діяльності, творчої й дослідницької роботи як уміння застосовувати інтегровані знання у процесі проектування.

Узагальнюючи теоретичний та практичний досвід, спираючись на раніше проведені педагогічні дослідження, визначено критерії виявлення типових особливостей професійно-педагогічної компетентності та встановлено три рівні їх сформованості.

1-рівень низький - передбачає наявність загальних уявлень про технологічний складник професійної компетентності на основі розроблених стандартів відповідного 
профілю підготовки. Знання із профільних дисциплін мають поверховий ситуативний характер. Студенти, що перебувають на першому рівні, відрізняються пасивністю у продуктивній художньо-конструкторській діяльності, мають низький рівень мотивації та самооцінки. Для таких студентів характерною $є$ пасивність на заняттях. Низький рівень засвідчує про те, що мотиви проектної самоосвіти здебільшого стихійні, а потреби відсутні, знання носять розрізнений, безсистемний характер, студент не вміє працювати самостійно і потребує стимулювання й постійного контролю, наявності зразка виконання діяльності.

2-й рівень середній - студенти усвідомлюють значиущість технологічної підготовки для майбутньої професійно-педагогічної діяльності, володіють базовими знаннями 3 профільних спеціальних дисциплін та їх застосування у типових ситуаціях. Художньо-конструкторські та технологічні здібності недостатньо розвинені, але мотиви досягнень мають стійкий характер. Студенти другого рівня сформованості технологічної компетентності відрізняються помірною активністю та завищеною самооцінкою. Студент середнього рівня розуміє необхідність зв'язку самоосвіти з особистими та професійними інтересами, уміє самостійно працювати 3 основними джерелами інформації й організувати свою самоосвітню проектну діяльність, вибравши для цього необхідні методи та форми, на певних етапах користується допомогою викладача.

3-й рівень високий - передбачає сформованість системи технологічних знань й умінь i наявність стійкого інтересу до їх практичного застосування. Студенти зорієнтовані на застосування технологічних знань та умінь, адекватно оцінюють свою роль у виконанні комплексних колективних завдань, прагнуть до самореалізації та самоактуалізації. Високий рівень означає, що студент не тільки глибоко розуміє необхідність самоосвітньої проектної діяльності, але й здатний чітко і самостійно формулювати цілі, конкретизувати їх у професійних задачах, визначати ефективні шляхи їх вирішення, уміє раціонально використовувати у своїй діяльності різні інформаційні джерела, управляє процесом самоосвіти.

Модульна система навчання в підготовці вчителя технологій $\epsilon$ найбільш ефективною 3 багатьох причин: як одна 3 умов Болонського процесу; як така, що формує самостійність студентів у навчанні та оцінюванні; розкриває шляхи до використання на практиці сучасних освітніх технологій. Модульна система впроваджена в навчальний процес під час вивчення дисциплін швейного спрямування i передбачає виконання комплексу різнорівневих завдань самостійної роботи студентами та здійснення самоконтролю та взаємоконтролю за результатами їх виконання.

Під професійною компетентністю розуміємо теоретичну, технологічну (практичну), а також моральну і психологічну готовність особистості виконувати функції, що входять до ії обов'язків і прав відповідно до повноважень певної посади або певної професійно-фахової спрямованості.

Компетенції - упорядкована сукупність методологічних, загально теоретичних, спеціально-теоретичних (фахово-професійних) знань та адекватних для їх реалізації технологічних умінь, об’єктивно необхідних для якісної діяльності особистості, яка працює у професійно-фаховій галузі (науково-викладацькі, наукові, методичні працівники, вчителі і т. ін.).

Зі зміною ситуації повинні змінитися функції вчителів технологій, а відповідно і ïх підготовка. Майбутні вчителі технологій повинні бути спеціалістами високого рівня професіоналізму, широкої ерудиції й такими, що володіють майстерністю перетворювальної діяльності. Особливо гостро нині постало питання про формування 
нового типу мислення вчителя - так званого, проектного, про розвиток його проективних здібностей, активне залучення до проектної діяльності.

Модульна система навчання, що спрямовує сучасну освіту на особистість, вимагає враховувати певні аспекти, зокрема: зміну головної мети технологічної освіти; зважати на особливу роль міжпредметних зв'язків у технологічній освіті; особистісну орієнтацію майбутнього вчителя технологій на неперервну освіту, що передбачає постійне оновлення технологічних знань та вмінь.

1. Балыхин Г. А. Управление развитием образования: организационноэкономический аспект / Григорий Артемович Балыхин. - М. : Экономика, 2003. 427 c. 2. Банько Н. А. Формирование профессионально-педагогической компетентности как компонента профессиональной подготовки менеджеров: [монография] / Н. А. Банько. - Волгоград : ВолгГТУ. - 2004. - 75 с. 3. Борисенко Н. Професійна підготовка майбутніх учителів технологій в умовах сучасного освітнього простору / Надія Борисенко // Проблеми підготовки сучасного вчителя: збірник наукових праць Уманського державного педагогічного університету імені Павла Тичини / [ред. кол. : Побірченко Н. С. (гол. ред.) та ін.]. - Умань : ПП Жовтий О. О., 2011. - Випуск 4. - Частина 2. - С. 295-301. 4. Иголкина М. И. Педагогические условия обеспечения компетентностного похода в подготовке педагога : дис. ... канд. пед. наук/ Мария Ивановна Иголкина / 13.00.01 «Общая педагогика, история педагогики образования».- M., 2008 [Электронный ресурс].- Режим доступа: http://nauka-pedagogika.com\pedagogika-13-00-01/disertaciya-pedagogicheskie-uslo

5. Тименко В. П. Початкова дизайн-освіта: теорія i практика формування конструктивних умінь особистості : [монографія] / Володимир Петрович Тименко. К. : Педагогічна думка, 2010. - 380 с. 6. Хазова Л. В. Концептуальные основы и опыт модернизации образования: гуманистические и гуманитарные аспекты / Л. В. Хазова. - Красноярск: Изд-во КГТУ, 1997. - 184 с. 7. Чернышева Е. И. Форимирование профессиональной компетентности будущих педагогов в развитии технологического мышления: дис. ... канд. пед. наук : 13.00.08, 13.00.01 / Чернышева Елена Ивановна. - Воронеж, 2005. - 182 с.

УДК 378:[37.011.3-051]:62/64

Світлана Кучер

\section{ОЦІНЮВАННЯ ПРОЕКТНОЇ ДІЯЛЬНОСТІ МАЙБУТНІХ УЧИТЕЛІВ НА ОСНОВІ ВИКОРИСТАННЯ ІНФОРМАЦЙНО-КОМУНІКАЦЙНИХ ТЕХНОЛОГІЙ (ЗА ПРОГРАМОЮ INTЕL «НАВЧАННЯ ДЛЯ МАЙБУТНЬОГО»)}

Кучер С. Л. Оцінювання проектної діяльності майбутніх учителів на основі використання інформаційно-комунікаційних технологій (за програмою Intel «Навчання для майбутнього»).

У статті розглядаються можливості впровадження програми Intel «Навчання для майбутнього в Україні» у процес оцінювання результатів творчого проектування майбутніх учителів технологій.

Ключові слова: інформаційно-комунікаційні технології (ІКТ), оцінювання, технологічна освіта, навчальні проекти, освітні програми Intel.

Кучер С. Л. Оценка проектной деятельности будущих учителей на основе использования информационно-коммуникационных технологий (по программе Intel «Обучение для будущего»). 